\title{
The Effect of Output Requirement on the Acquisition of Grammatical Collocations by Iranian EFL Learners
}

\author{
Ehsan Rezvani \\ Department of English, Faculty of Foreign Languages, University of Isfahan, Isfahan, Iran \\ Email: rezvani_ehsan_1982@yahoo.com
}

\begin{abstract}
The present study investigated: (a) the effect of output requirement on the acquisition of grammatical collocations; and (b) the relative efficacy of output tasks in comparison with that of input enhancement with regard to the acquisition of grammatical collocations. Ninety homogenous adult Iranian intermediate EFL learners were randomly assigned to two experimental (EG1/EG2) and a control group (CG). A pre-test was given to the three groups to measure the students' knowledge of collocations prior to any treatment. The students in EG1 were required to do certain output tasks dealing with the collocations in focus after reading a passage whereas for those in EG2 the same target forms were visually enhanced. The students in the CG received neither visually enhanced input, nor output tasks and they were asked to simply read the passage, and answer some questions about it. After the treatment phase, a post-test was administered to measure the gains. The results indicated that both output and input enhancement exert a significant effect on the acquisition of grammatical collocations by the learners. It was also found that input enhancement group outperformed the output group; however; the observed difference was not statistically significant. Accordingly, it can be claimed that an implicit and unobtrusive method such as input enhancement can be as effective as an output task which requires actual production of language on the part of L2 learners.
\end{abstract}

Index Terms - Output Hypothesis, output task, input enhancement, grammatical collocations

\section{INTRODUCTION}

Over the past decades, the question of how to teach grammar has been one of the most challenging and controversial issues in SLA (Celce-Murcia, 1991; Ellis, 2006). Since there is now a general consensus among SLA researchers that attention plays a critical role in language learning, a great deal of research has focused on what method or what types of tasks better promote learners' noticing of certain linguistic targets in the input. Many studies which have been carried out under the rubric of input enhancement (Sharwood Smith, 1991, 1993, 1994) and Focus on Form (FonF) (Doughty and Williams, 1998; Long, 1991; Doughty, 2001) as well as the more recent research on the noticing function of output (Izumi et al., 1999; Izumi and Bigelow, 2000; Izumi, 2002) are based on the assumption that drawing learners' attention to target forms, as they arise incidentally in lessons whose overriding focus is meaning and communication, makes it easier for them to acquire form and meaning simultaneously.

Along the same line of research, an important issue which has not received sufficient attention from researchers and has produced quite mixed results is the effect of output tasks, in comparison with comprehension tasks, on noticing and acquisition of target forms. More specifically, the results of research on the question of whether output tasks better promote noticing and acquisition of certain targeted linguistic forms than non-output task conditions has been quite inconclusive (Izumi, 2002; Izumi et al., 1999; Izumi and Bigelow, 2000). Therefore, more research needs to be conducted in this area to explore the relative efficacy of output tasks in SLA.

The present study aims at investigating the potential effect of output tasks on the acquisition of a certain number of grammatical collocations by Iranian intermediate EFL learners. Moreover, this study seeks to compare the facilitative effect of output tasks with that of visual input enhancement on the acquisition of certain grammatical collocations.

\section{BACKGROUND}

\section{A. Attention, Noticing and Input Enhancement}

An increasingly well-established line of work has underscored the role of noticing and attention in SLA (Schmidt, 1990, 1993, 1994, 1995, 2001; Tomlin and Villa, 1994; Robinson, 1995). Moreover, more emphasis has been placed on the importance of drawing learners' attention to certain linguistic features which might otherwise go unnoticed (Sharwood Smith, 1991, 1993, 1994). In fact, recent SLA research has increasingly established the legitimacy of a FonF approach to language teaching (Doughty \& Williams, 1998). Proponents of FonF approaches (input enhancement, in particular) claim that the best way to learn a language is not by treating it as an object of study, but by experiencing it meaningfully as a tool for communication with certain target structures physically highlighted and embedded within 
communicative activities (Doughty \& Williams, 1998; Sharwood Smith, 1991, 1993, 1994). One of the ways of directing learners' attention to formal aspects of language is visual input enhancement, which is an implicit and unobtrusive means to increase the perceptual salience of the target forms via a variety of typographical techniques such as underlining, bolding, highlighting, etc. Many studies have focused on the effects of visual input enhancement (Alanen, 1995; Doughty, 1991; Shook, 1994; Williams, 1999; Gharaee, 2002), and this study will also have an eye on it.

\section{B. The Attention-drawing Role of Output Tasks}

In the 1980s, the word "output" was used to refer to the outcome, or product, of the language acquisition process. Output was synonymous with "what the learner has learned". However, with the proposal of Swain's Output Hypothesis (1985, 1995, 2000, 2005), output has come to be deemed not merely as an end product of learning, but as an important factor to promote L2 learning. It has been noted that producing the target language provides learners with unique opportunities for a level of processing (i.e., syntactic processing) that may be needed for the development of target-like proficiency and higher accuracy (Izumi and Bigelow, 2000; Swain and Lapkin, 1995).

Of the four functions of output posited by Swain $(1993,1995,1998)$, the focus of the present study is in line with the noticing function. Swain claims that while learners attempt to produce the target language (vocally or silently), they may notice that "they do not know how to say (or write) precisely the meaning they wish to convey" (Swain, 1995, p.474). This, in turn, may prompt second language learners to recognize consciously some of their linguistic problems and bring their attention to what they need to solve their linguistic deficiency.

Relatively few studies to date have focused on the noticing function and the effect of output in SLA, and the results have been inconclusive. Izumi and his colleagues conducted a series of meticulously designed studies to examine whether output prompts learners to notice and subsequently learn certain grammatical features (Izumi et al., 1999; Izumi and Bigelow, 2000; Izumi, 2002).

To investigate the above-mentioned issue, Izumi et al. (1999) and Izumi and Bigelow (2000) conducted a two-stage study in which they focused on the English past hypothetical conditionals, and compared an experimental group that was given output opportunities and subsequent exposure to relevant input and a control group that was exposed to the same input first and then asked to answer comprehension questions on the input. In both studies the output tasks were a reconstruction writing task and an essay-writing task, and the two studies were the same in every aspect except in the order of presenting the two output tasks. In Izumi et al. (1999), the reconstruction task was given in phase 1and one week after phase 1, an essay-writing task was given in phase 2, whereas in Izumi and Bigelow (2000), the order of tasks was reversed to examine if task ordering plays any role in accounting for the results. The findings revealed that the effects of output in promoting noticing of the form were not significant in the two studies. Regarding the acquisition issue, the studies revealed a contrasting finding: Izumi et al. (1999) found the experimental group made a greater improvement on the production test than did the control group, while Izumi and Bigelow (2000) found no advantage for the experimental group in gains on any of the post-tests.

Izumi (2002), building on previous studies, aimed at investigating whether output requirement (reconstruction task) and visual input enhancement, utilized together or separately, promote noticing and learning of English relativization (object-of-preposition type of relative clauses) among ESL learners. The findings considering noticing were somewhat mixed; nevertheless, those considering acquisition were much clearer and revealed a significant effect for output, none for input enhancement, and no interaction effect. More specifically, those students who reconstructed the text learned more about relativization than those who engaged in input comprehension activities irrespective of whether the input was enhanced.

In sum, the inconclusive findings by several researchers who have investigated the noticing function of output and its subsequent impact on L2 learning, together with the importance of this issue in current SLA warrants further studies in this area. The present study is an attempt to examine the effect of output (reconstruction tasks) on the acquisition of certain grammatical collocations by Iranian intermediate EFL learners.

\section{RESEARCH QUESTIONS}

Drawing on the psycholinguistic rationale and empirical research on output (Swain, 1985, 1993, 1995, 2000, 2005; Izumi et al., 1999; Izumi and Bigelow, 2000; Izumi, 2002), and to further our understanding of the effect of output on acquisition in SLA, the present study focused on the following questions:

1) Does output requirement exert a significant influence on the acquisition of grammatical collocations by Iranian intermediate EFL learners?

2) Does visual input enhancement have a significant influence on the acquisition of grammatical collocations by Iranian intermediate EFL learners?

3) Is there a significant difference between visual input enhancement and output requirement with regard to the influence these two approaches to teaching exert on the acquisition of grammatical collocations by Iranian intermediate EFL learners? 


\section{A. Participants}

The participants in this study were 120 Iranian intermediate EFL learners, age 19-27, attending a language center in Esfahan, Iran. In order to make sure in objective terms that these learners were truly homogenous with regard to their English proficiency level, a Nelson English Language Proficiency Test (Fowler and Coe, 1976) was given to them. Having obtained the proficiency test results, the researcher decided to choose those participants whose score range fell one standard deviation above and below the mean (i.e. mean \pm 1 ). This being so, 90 students met this homogeneity criterion and were thus selected to serve as the participants of this study. Later, they were randomly assigned to the three groups (two experimental and one control) involved in the study (30 students each).

\section{B. Linguistic Target}

One of the fundamental components of language proficiency which make a positive contribution to the ways learners speak, listen, read and write is a sufficient knowledge of collocations. It has been suggested that pre-fabricated language chunks and routinized formulae play an important role in language acquisition and use (Nattinger \& DeCarrico, 1992). The existing literature on collocations clearly indicates that a good knowledge of collocations and high language proficiency are tightly interrelated (Zhang, 1993; Ellis, 1999; Gitsaki \& Taylor, 1997). Focusing on the importance of collocations to linguistic competence, Ellis (1999) contends that learners' fluent use of word sequences (i.e. frequent collocations, phrases, and idioms) is a very important index of native-like competence. In sum, it can be claimed that an increasing mastery of the most basic words and structures of the language, which becomes possible through strengthening the students' collocational power, results in a higher level of competence and communicative ability (Lewis, 2000). It is, therefore, important that L2 learners have a good knowledge of the particular patterns in which words are frequently grouped. If collocational associations are not learned as part of the L2 knowledge, the learners' speech or writing will be immediately judged as non-native or simply as weird. In other words, learners' lack of collocational knowledge makes them sound unnatural and not very competent in their language use- a prevalent problem in the present EFL situation in Iran. Some examples of wrongly used collocations are *good in swimming, *afraid from, *ability for doing something, *fascinated about something, * a problem of, etc.

Considering the importance of collocations, this study focuses on the acquisition of certain grammatical collocations by Iranian intermediate EFL learners. Benson (1989) defines a grammatical collocation as a phrase which is composed of a preposition and a main word (noun, verb, or adjective) or a structural pattern such as a clause or a two-part verb. In his view, there are eight major types of grammatical collocations in English; however, given the limitations of space, this study will focus only on three of the eight types of grammatical collocations proposed by Benson (1989); namely, Type One (N.+ Prep.), Type Five (Adj.+ Prep.), and Type Eight (V.+ Prep.).

\section{Procedure}

The experimental sequence of the study was carried out over a period of around twelve weeks. As noted earlier, 90 homogenous learners were randomly assigned to three groups. There were two experimental (EG1 \& EG2) and one control group (CG). One week prior to the first treatment session, all the participants took the pre-test which consisted of items designed to elicit the grammatical collocations in question and assess the learners' knowledge of these collocations prior to any type of treatment (see Appendix A for sample questions of the pre- and the post-test). Then, every group underwent ten different treatment sessions. There was an interval of around 5 or 6 days between the treatment sessions, and the post-test followed the last teaching session a week later. In an attempt to control for outside exposure to the target form, after completing the post-test, the learners were asked whether they had consulted with anyone or anything about the target form. The data from those who reported having done so were discarded. For this reason, the groups slightly differed in size; there were 26, 25, 28 participants in EG1, EG2 and CG, respectively.

\section{Treatment}

After the pre-test and during the treatment phase of the study, participants in all the three groups separately attended ten sessions of treatment in which they were all given a set of ten reading passages which were selected to serve the purpose of presenting the participants with the grammatical collocations in focus (see Appendix B for sample of reading passages). These reading passages were identical in content; however, they fulfilled different purposes in the treatment session. In all the ten treatment sessions for each of the groups the following procedure was run:

As for the students in EG1, after reading the text, they were asked to reconstruct some sentences based on the information in the input passage as accurately as possible. In other words, without looking back at the text, the students were encouraged to use the vocabulary prompts (cue words) provided for them to write a grammatical sentence about the events they had read about in the passage (see Appendix $C$ for sample reconstruction task items). In fact, students in EG1 were engaged in an output task (reconstruction task) struggling to produce grammatical English sentences including grammatical collocations.

The reading passages given to students in EG2 were identical to those of the other two groups in content; nevertheless, the grammatical collocations in focus were made salient for EG2 learners through typographical techniques such as bolding and underlining. In other words, EG2 learners received enhanced input in their treatment sessions because the grammatical collocations were made visually salient via visual input enhancement (see Appendix B for sample texts). After reading the passage with the collocations highlighted, the students were supposed to answer 
some reading comprehension question about the text. That is, unlike EG1 learners, participants in EG2 did not receive output tasks and were not encouraged to produce language including the target forms.

Students in the third group, who served as the CG, were asked to read the passages and answer some reading comprehension questions about the passage. In fact, they received neither an output task nor enhanced input.

\section{E. Tests and Scoring Procedure}

Since this study was designed to focus on the acquisition of grammatical collocations by Iranian intermediate EFL learners after certain types of treatment were employed, a pre-test and a post-test (see Appendix A for sample questions) were constructed by the researcher to assess the subjects' knowledge of grammatical collocations prior to and after the treatment phase of the study. Both tests comprised 30 multiple-choice items from which the grammatical collocations were missing, and the subjects were required to complete the sentences by selecting the correct choice. It should be noted that since the pre- and post-test utilized in this study were researcher-made ones, they were both piloted prior to use and an alpha Cronbach method was applied to guarantee their reliability. Reliability indexes revealed that the researcher-made tests were acceptable for the purpose of the study.

In scoring the pre-test and the post-test, each correct answer was given a single point, and all the correct answers added up to a total sum. There was no negative point for the wrong answers or for the items not answered at all.

\section{STATISTICAL ANALYSIS AND RESULTS}

\section{A. Pre-test of the Study}

For the groups to be comparable and for an experiment like this to be meaningful, the researcher had to make sure that the learners in the experimental and control groups enjoyed the same level of knowledge regarding the linguistic forms under investigation (i.e. grammatical collocations). To meet this requirement, a pre-test was given to all three groups to measure their knowledge of collocations in focus. Table 1 shows the descriptive statistics of the participants' mean scores on the pre-test across the three groups.

TABLE 1.

DESCRIPTIVE STATISTICS ON THE PRE-TEST

\begin{tabular}{|c|c|c|c|c|c|}
\hline & $\mathrm{N}$ & Minimum & Maximum & Mean & Std. Deviation \\
\hline EG1 & 26 & 11.00 & 18.00 & 14.3000 & 1.74494 \\
\hline EG2 & 25 & 12.00 & 17.00 & 14.3667 & 1.58296 \\
\hline CG & 28 & 12.00 & 18.00 & 14.2000 & 1.64841 \\
\hline
\end{tabular}

It can be seen in the above table that the mean scores for the three groups are statistically very close $(14.3000 \approx 14.3667 \approx 14.2000)$. Therefore, it can be concluded that the learners in the three groups did not differ greatly from one another in terms of their knowledge of the target forms in question. That is, the participants' prior knowledge of the target forms was statistically almost equal.

\section{B. Research Question 1}

The first research question asked whether output tasks exert a significant influence on the acquisition of grammatical collocations by Iranian intermediate EFL learners. To investigate the impact of output tasks on the subjects' performance on grammatical collocations, a paired-samples t-test was run. The t-test was intended to compare the obtained mean scores of the participants in EG1 on the pre- and post-test to indicate the effectiveness of the treatment. The descriptive statistics, along with the results of the t-test for EG1, are presented in Tables 2 and 3, respectively.

TABLE 2

PAIRED-SAMPLES DESCRIPTIVE STATISTICS FOR EG1

\begin{tabular}{|lr|c|c|c|c|}
\hline & & Mean & N & Std. Deviation & Std. Error Mean \\
\hline Pair & PRETEST & 14.3000 & 26 & 1.74494 & .31858 \\
1 & POSTTEST & 25.1000 & 26 & 2.33932 & .42710 \\
\hline
\end{tabular}

TABLE 3

PAIRED-SAMPLES T-TEST RESULTS FOR EG1

\begin{tabular}{|c|c|c|c|c|c|c|c|c|}
\hline & \multicolumn{5}{|c|}{ Paired differences } & \multirow[t]{3}{*}{$\mathrm{t}$} & \multirow[t]{3}{*}{ df } & \multirow[t]{3}{*}{ Sig. (2-tailed) } \\
\hline & \multirow[t]{2}{*}{ Mean } & \multirow[t]{2}{*}{$\begin{array}{c}\text { Std. } \\
\text { Deviation }\end{array}$} & \multirow[t]{2}{*}{$\begin{array}{l}\text { Std. Error } \\
\text { Mean }\end{array}$} & \multicolumn{2}{|c|}{$\begin{array}{l}95 \% \text { Confidence Interval } \\
\text { of the Difference }\end{array}$} & & & \\
\hline & & & & Lower & Upper & & & \\
\hline Pre/posttest & -10.8000 & 1.15669 & .21118 & -11.2319 & -10.3681 & -51.141 & 25 & .000 \\
\hline
\end{tabular}

Given the information in Table 2, one can clearly see that the mean score obtained on the post-test (25.1000) is higher than the one obtained on the pre-test (14.3000). However, a paired-samples t-test was run to ensure that the observed difference was significant. Table 3 shows that there is a significant difference in the scores obtained from the pre- and post-test because the probability value is substantially smaller than the specified critical value $(0.000<0.05)$. Accordingly, it can be claimed that output tasks were shown to exert a positive effect on the acquisition of the given collocations. 


\section{Research Question 2}

The second research question asked whether input enhancement has a significant effect on the acquisition of grammatical collocations by Iranian intermediate EFL learners. To answer this question, a paired-samples t-test was conducted. Tables 4 and 5 provide the descriptive statistics, along with the results of the given paired-samples t-test.

TABLE 4

PAIRED-SAMPLES DESCRIPTIVE STATISTICS FOR EG2

\begin{tabular}{|lr|c|c|c|c|}
\hline & & Mean & $\mathrm{N}$ & Std. Deviation & Std. Error Mean \\
\hline Pair & PRETEST & 14.3667 & 25 & 1.65015 & .30127 \\
1 & POSTTEST & 25.8333 & 25 & 1.66264 & .30355 \\
\hline
\end{tabular}

TABLE 5

PAIRED-SAMPLES T-TEST RESULTS FOR EG2

\begin{tabular}{|c|c|c|c|c|c|c|c|c|}
\hline & \multicolumn{5}{|c|}{ Paired differences } & \multirow[t]{3}{*}{$\mathrm{t}$} & \multirow[t]{3}{*}{ df } & \multirow[t]{3}{*}{ Sig. (2-tailed) } \\
\hline & \multirow[t]{2}{*}{ Mean } & \multirow[t]{2}{*}{$\begin{array}{c}\text { Std. } \\
\text { Deviation }\end{array}$} & \multirow[t]{2}{*}{$\begin{array}{l}\text { Std. Error } \\
\text { Mean }\end{array}$} & \multicolumn{2}{|c|}{$\begin{array}{c}95 \% \text { Confidence Interval } \\
\text { of the Difference }\end{array}$} & & & \\
\hline & & & & Lower & Upper & & & \\
\hline Pre/posttest & -11.4667 & 2.01260 & .36745 & -12.2182 & -10.7151 & -31.206 & 24 & .000 \\
\hline
\end{tabular}

On a closer inspection of the mean scores given in Table 4, one can clearly see that the subjects in EG2 gained a higher mean score on the post-test after receiving the treatment (Pos-test=25.8333>Pre-test=14.3667). However, the researcher had to go further to find out whether or not the observed difference was significant. Therefore, the results of the t-test were taken into account. It can be concluded from the information presented in Table 5 that there is a significant difference in the performance of the participants on the pre- and post-test. This conclusion can be drawn because the probability value in Table 5 is observed to be 0.000 which is less than the critical value (0.05). In sum, it can be maintained that input enhancement has a positive impact on the acquisition of grammatical collocations by Iranian intermediate EFL learners.

\section{Research Question 3}

The last research question asked whether there is a significant difference between visual input enhancement and output requirement with regard to the influence these two approaches to teaching exert on the acquisition of grammatical collocations by Iranian intermediate EFL learners. The descriptive statistics of the scores obtained from the post-test demonstrate that the members of the experimental groups (EG1and2) outperformed those of the control group (CG). In fact, one can see in Table 6 that the mean score obtained by EG2 (25.8333) exceeds the mean score obtained by EG1 (25.1000) which is, in turn, higher than the mean score belonging to CG (14.5333).

TABLE 6.

DESCRIPTIVE STATISTICS ON THE POST-TEST

\begin{tabular}{|c|c|c|c|c|c|c|c|c|}
\hline & \multirow[t]{2}{*}{$\mathrm{N}$} & \multirow[t]{2}{*}{ Mean } & \multirow{2}{*}{$\begin{array}{c}\text { Std. } \\
\text { Deviation }\end{array}$} & \multirow[t]{2}{*}{ Std. Error } & \multicolumn{2}{|c|}{ 95\% Confidence Interval for Mean } & \multirow[t]{2}{*}{ Minimum } & \multirow[t]{2}{*}{ Maximum } \\
\hline & & & & & Lower Bound & Upper Bound & & \\
\hline EG1 & 26 & 25.1000 & 2.33932 & .42710 & 24.2265 & 25.9735 & 22.00 & 30.00 \\
\hline EG2 & 25 & 25.8333 & 1.66264 & .30355 & 25.2125 & 26.4542 & 23.00 & 30.00 \\
\hline $\mathrm{CG}$ & 28 & 14.5333 & 1.61316 & .29452 & 13.9310 & 15.1357 & 12.00 & 18.00 \\
\hline Total & 79 & 21.8222 & 5.52131 & .58200 & 20.6658 & 22.9786 & 12.00 & 30.00 \\
\hline
\end{tabular}

Having gained some rudimentary information about the differences in the performance of the members of the three groups on the post-test, the researcher had to determine whether or not the observed differences were significant at the critical value (Sig.) of $\mathrm{p}<0.05$. Therefore, a one-way between-groups ANOVA was conducted. Table 7 provides the results of the ANOVA.

TABLE 7.

THE RESULTS OF ANOVA ON THE POST-TEST

\begin{tabular}{|c|c|c|c|c|c|}
\hline & Sum of Squares & df & Mean Square & F & Sig. \\
\hline Between Groups & 2398.822 & 2 & 1199.411 & 331.969 & .000 \\
Within Groups & 314.333 & 76 & 3.613 & & \\
Total & 2713.156 & 78 & & & \\
\hline
\end{tabular}

On a closer inspection of Table 7, one can conclude that the three groups differed significantly with respect to their mean scores on the post-test because the significant value is observed to be 0.000 , which is less than the critical value (0.05). Although the information presented in Table 7 is very revealing, it does not show where the observed differences lie. The researcher, therefore, had to run a Scheffe Post-hoc test. This post-hoc test indicates where the differences among the three groups (i.e. sets of scores) occur. Table 8 provides the results of the post-hoc test. 
TABLE 8

THE RESULTS OF THE POST-HOC TEST

\begin{tabular}{|c|c|c|c|c|c|c|}
\hline \multirow[t]{2}{*}{ (I) TEACHING } & \multirow[t]{2}{*}{ (J) TEACHING } & \multirow{2}{*}{$\begin{array}{l}\text { Mean Difference } \\
(\mathrm{I}-\mathrm{J})\end{array}$} & \multirow[t]{2}{*}{ Std. Error } & \multirow[t]{2}{*}{ Sig. } & \multicolumn{2}{|c|}{$95 \%$ Confidence Interval } \\
\hline & & & & & Lower Bound & Upper Bound \\
\hline EG1 & $\begin{array}{c}\text { EG2 } \\
\text { CG }\end{array}$ & $\begin{array}{c}-.7333 \\
10.5667 *\end{array}$ & $\begin{array}{l}.49078 \\
.49078\end{array}$ & $\begin{array}{l}.299 \\
.000\end{array}$ & $\begin{array}{c}-1.9036 \\
9.3964\end{array}$ & $\begin{array}{c}.4369 \\
11.7369\end{array}$ \\
\hline EG2 & $\begin{array}{l}\text { EG1 } \\
\text { CG }\end{array}$ & $\begin{array}{c}.7333 \\
11.3000^{*}\end{array}$ & $\begin{array}{l}.49078 \\
.49078\end{array}$ & $\begin{array}{l}.299 \\
.000\end{array}$ & $\begin{array}{c}-.4369 \\
10.1297\end{array}$ & $\begin{array}{c}1.9036 \\
12.4703\end{array}$ \\
\hline $\mathrm{CG}$ & $\begin{array}{l}\text { EG1 } \\
\text { EG2 }\end{array}$ & $\begin{array}{c}-10.5667 * \\
-11.3000\end{array}$ & $\begin{array}{l}.49078 \\
.49078\end{array}$ & $\begin{array}{l}.000 \\
.000\end{array}$ & $\begin{array}{l}-11.7369 \\
-12.4703\end{array}$ & $\begin{array}{c}-9.3964 \\
-10.1297\end{array}$ \\
\hline
\end{tabular}

As mentioned above, the post-hoc test was employed to show where exactly the differences lie. In the above table, if there is an asterisk (*) next to the values listed in the second column, this means that the groups being compared are significantly different from one another at the $\mathrm{p}<0.05$ level. In the first row of the table, the asterisk next to 10.5667 indicates that the difference between EG1 and CG is significant. Likewise, the difference between EG2 and CG appears to be significant because an asterisk can be seen next to 11.3000 in the second row of the table. In a nutshell, it can be claimed that CG is significantly different from EG1 and EG2, but there seems to be no significant difference between EG1 and EG2. As a result, it can be claimed that there is no significant difference between output requirement and input enhancement in terms of the influence they exert on the acquisition of grammatical collocations.

\section{DISCUSSION}

This study set out to investigate three research questions: (1) whether output tasks exert a significant influence on the acquisition of grammatical collocations by Iranian intermediate EFL learners; (2) whether input enhancement has a significant effect on the acquisition of grammatical collocations by Iranian intermediate EFL learners; and (3) whether there is a significant difference between visual input enhancement and output requirement with regard to the influence these two approaches to teaching exert on the acquisition of grammatical collocations by Iranian intermediate EFL learners. In brief, it was revealed that both output tasks and input enhancement have a positive impact on the acquisition of the target forms. Moreover, the findings indicated that these two methods were not significantly different with regard to the influence they exert on the acquisition of the target forms.

Firstly, the fact that the learners who engaged in output tasks and actual production of language did significantly better on the post-test suggests that having output opportunities was effective in developing learners' ability to use the target form more target-like or accurately. This is in line with Output Hypothesis proposed by Swain $(1985,1993,1995$, $1998,2000,2005)$. Swain $(1985,1995,2005)$ maintains that output should not be viewed merely as an end product of learning, but as an important factor to promote L2 learning. The findings of the first research question in the present study also lend empirical support to previous experimental studies (Swain and Lapkin, 1995; Izumi et al., 1999; Izumi, 2002; Song and Suh, 2008) which claim that producing the target language provides learners with unique opportunities for a level of processing (i.e., syntactic processing) that may be needed for the development of target-like proficiency or the enhancement of accuracy. On the other hand, Izumi and Bigelow (2000) reported contrasting findings regarding the acquisition. According to them, there was no significant difference in gains between those learners engaged in output tasks and those involved in non-output tasks. On the whole, it should be noted that relatively few studies to date have investigated this issue and their inconclusive findings demonstrate the need for further research.

Secondly, the fact that the learners who received input enhancement treatment made significant gains with regard to the acquisition of grammatical collocations is consistent with the general trend observed in the works of Sharwood Smith (1991, 1993, 1994), who is deemed as a pioneer in input enhancement studies. Sharwwod Smith (1994) contends that "the most obvious way to try to affect the subconscious processes beneficially is by making relevant evidence in the input specially salient" (p.178, emphasis in the original). In addition, the present findings are in line with the previous studies on the effects of visual input enhancement which yielded positive findings for the facilitative role of input enhancement (Shook, 1994; Doughty, 1991; Williams, 1999). There are, however, a number of other studies showing incompatible results with the present findings. Such studies showed no significant effects or only limited facilitative effects for input enhancement (Alanen, 1995; Robinson, 1997; White, 1998; Gharaee, 2002).

Finally, it was found that the learners who engaged in the output tasks did not perform better on the post-test than those who did a kind of non-output task (input enhancement). The fact that the output task group and the input enhancement group showed comparable gain scores on the post-test indicates that output tasks were not significantly more effective than input enhancement task in facilitating development of learners' receptive knowledge. Accordingly, it can be claimed that an implicit and unobtrusive method such as input enhancement can be as effective as an output task which requires actual production of language on the part of L2 learners. On the other hand, no difference in the relative efficacy of these two methods may be attributable to the inadequacy of 'reconstruction' as a kind of output task. Perhaps other output tasks requiring deeper levels of processing and production will show more significant effects for output tasks in SLA. 
This study may have implications for L2 materials developers and teachers. It revealed that both output tasks and input enhancement lead to significant acquisition of target forms. Therefore, materials developers and teachers may use them as class activities that can appropriately control the learners' attentional resources without losing sight of meaning. Moreover, it would be useful in a classroom to devise and use these types of tasks so that learners can notice, take in, acquire and/or produce target forms in a meaningful context.

\section{LIMITATIONS AND FURTHER RESEARCH}

Acknowledging some limitations of the present study, certain suggestions can be made for further research. Firstly, this study adopted a short-term treatment with rather limited exposure to target forms. Further research can focus on the potential effects of longer-term treatments with larger amounts of exposure to target forms. Secondly, the findings of this study showed the positive effect of output tasks and input enhancement on the acquisition of certain grammatical collocations; however, not all linguistic features or rules may be equally amenable to these tasks. Thus, other researchers may focus on different target forms. Thirdly, the participants in this study were all intermediate learners. Another question which merits more investigation is whether or not students with other levels of proficiency (i.e. elementary and advanced) also benefit from output tasks and input enhancement. Finally, this study used only one type of output task - reconstruction task. Future research can focus on the effects of other types of output tasks.

\section{APPENDIX A. SAMPLE Questions FROM THE PRE-/POST-TEST}

Read the following exchanges carefully and choose the correct answers.

1. A: Is he a good photographer?

B: Yes, he has perfect skills .... photography.

a) in

b) on

c) for

2. A: Hey, why are you so mad .... me?

B: Because you told the teacher that I cheated on the test.

3. A: Do you know I've failed my math test again?

B: Yes, that's why I'm so disappointed .... you.

a) at

b) from

c) over

4. A: What is the worst thing about being an only child?
a) at
b) about
c) in

B: The biggest problem .... being an only child is that you always feel lonely. a) about

5. A: Did he finally break into movies?
B: Yes he did, because he had a real enthusiasm .... movies.
a) in
b) about

b) with

c) on

6. A: Come on! Tell me! What's the verdict?

B: Don't worry. All the members agreed .... your new proposal. a) over $\quad$ b) on $\quad$ c) at

\section{APPENDIX B. SAMPLE EXCERPT FROM THE TEXTS USED DURING THE TREATMENTS}

(Target forms in focus were bolded for EG2 but they were in plain form for EG1\& CG)

I grew up in the south of Spain in a little community called Estepona. I was sixteen when one morning, my father, who was always doubtful about my skills in driving, told me I could drive him into a remote village called Mijas, about 18 miles away, on the condition that I take the car to be serviced by Mr. Robins at a nearby garage. We had to go all the way to Mijas because my father believed in Mr. Robin's expertise in fixing any potential problems with a car. It was a good opportunity for me to prove it to my dad that I was good at driving, so I readily accepted his offer. I drove dad into Mijas and promised to pick him up at 4 p.m., then drove to a nearby garage and dropped off the car. Because I had a few hours to spare, I decided to catch a couple of movies at a theater near the garage. In fact, I used to have a real enthusiasm for movies when I was a child, so I headed for the theater. However, I became so immersed in the movies that I completely lost track of time. When the last movie had finished, I looked down at my watch. It was six o'clock. I was two hours late....

\section{APPENDix C. SAMPLE VocABUlary PROMPTS USED FOR THE RECONSTRUCTION OUTPUT TASK USED FOR EG1}

Considering the information in the text, write complete sentences using the vocabulary given below.

- The boy/ashamed/telling/lies/his father

- Possible response: The boy was ashamed of telling lies to his father.

- The boy/confessed/his trip/movie theatre

- Possible response: The boy confessed to his trip to the movie theatre.

- The father/disappointed/his son

- Possible response: The father was disappointed in his son.

- The boy/decided/make/pleas/merci

- Possible response: The boy decided to make pleas for merci. 
[1] Alanen, R. (1995). Input enhancement and rule presentation in second language acquisition. In R. Schmidt (ed.), Attention and awareness in foreign language learning and teaching. Honolulu: University of Hawai'i Press, 259-302.

[2] Benson, M. (1989). The structure of collocational dictionary. The International Journal of Lexicography 2, 1-14.

[3] Celce-Murcia, M. (1991). Grammar pedagogy in second and foreign language teaching. TESOL Quarterly 25, 459-480.

[4] Doughty, C. (1991). Second language instruction does make a difference. Studies in Second Language Acquisition 13, $341-469$.

[5] Doughty, C. (2001). Cognitive underpinnings of focus on form. In P. Robinson (Ed.), Cognition and L2 Instruction. Cambridge Cambridge University Press, 206-257.

[6] Doughty, C., and Williams J. (1998). Focus-on-form in classroom second language acquisition. Cambridge: Cambridge University Press.

[7] Ellis, N. (1999). Cognitive approaches to SLA. Annual Review of Applied Linguistics 19, 22-42.

[8] Ellis, R. (2006). Current issues in the teaching of grammar: an SLA perspective. TESOL Quarterly 40, 83-107.

[9] Fowler, W. S., and Coe, N. (1976). Nelson English Language Tests. London: Bulter and Tannerltad.

[10] Gharaee, M. R. (2002). The effect of input enhancement on structure rule acquisition by Iranian EFL learners. Unpublished MA Thesis, English Language Department, Isfahan University: Iran.

[11] Gitsaki, C., and Taylor, P. R. (1997). English collocations and their place in EFL classrooms. [On-line] available at http://www. wordcollocations/twotech.htm.

[12] Izumi, S. (2002). Output, input enhancement, and the noticing hypothesis: An experimental study on ESL relativization. Studies in Second Language Acquisition 24, 541-577.

[13] Izumi, S., and Bigelow, M. (2000). Does output promote noticing and second language acquisition? TESOL Quarterly 34, 239 278

[14] Izumi, S., Bigelow, M., Fujiwara, M., and Fearnow, S. (1999). Testing the output hypothesis: Effects of output on noticing and second language acquisition. Studies in Second Language Acquisition 21, 421-452.

[15] Lewis, M. (2000). Teaching collocations: Further developments in the lexical approach. Hove: Language Teaching Publications

[16] Long, M. H. (1991). Focus-on-form: A design feature in language methodology. In K. De Bot, R. Grinsberg and C. Kramsch (eds.), Foreign Language Research in Cross-cultural Perspective. Amsterdam: John Benjamins, 39-52.

[17] Nattinger, J., and De Carrico, J. (1992). Lexical phrases and language learning. Oxford: Oxford University Press.

[18] Robinson, P. (1995). Attention, memory, and the "Noticing" hypothesis. Language Learning 45, 283-331.

[19] Robinson, P. (1997). Generalizability and automaticity of second language learning under implicit, incidental, enhanced, and instructed conditions. Studies in Second Language Acquisition 19, 223-247.

[20] Schmidt, R. (1990). The role of consciousness in second language learning. Applied Linguistics 112, 129-158.

[21] Schmidt, R. (1993). Awareness and second language acquisition. Annual Review of Applied Linguistics 11, $206-226$.

[22] Schmidt, R. (1994). Implicit learning and cognitive consciousness of artificial grammars and SLA. In N. Ellis, (ed.), Implicit and explicit learning of languages. London: Academic Press.

[23] Schmidt, R. (1995). Consciousness and foreign language learning: a tutorial on the role of attention and awareness in learning. In R. Schmidt (ed.), Attention and awareness in foreign language learning. Honolulu: Second language teaching and curriculum center, 1-63.

[24] Schmidt, R. (1998). The centrality of attention in SLA. University of Hawai'i Working Papers in ESL 16, 2, 1-34.

[25] Schmidt, R. (2001). Attention. In P. Robinson (ed.), Cognition and second language instruction. Cambridge: Cambridge University Press, 3-32.

[26] Sharwood Smith, M. (1991). Speaking to many minds: On the relevance of different types of language information for the L2 learner. Second Language Research 7, 118-132.

[27] Sharwood Smith, M. (1993). Input enhancement in instructed SLA. Studies in Second Language Acquisition 15, 165-179.

[28] Sharwood Smith, M. (1994). Second language learning: Theoretical foundations. New York, NY: Longman.

[29] Shook, D. (1994). FL/L2 reading, grammatical information, and input-to-intake phenomenon. Applied Language Learning 5, 57-93.

[30] Song, M. J., and Suh, B. R. (2008). The effects of output task types on noticing and learning of the English past counterfactual conditional. System 36, 295-312.

[31] Swain, M. (1985). Communicative competence: some roles of comprehensible input and comprehensible output in its development. In S. Gass, and C. Madden (Eds.), Input in Second Language Acquisition. Rowley: Newbury House, 235-253.

[32] Swain, M. (1993). The output hypothesis: just speaking and writing aren't enough. The Canadian Modern Language Review 50 $158-164$

[33] Swain, M. (1995). Three functions of output in second language learning. In: G. Cook, and B. Seildhofer (Eds.), Principles and Practice in Applied Linguistics: Studies in Honor of H.G. Widdowson. Oxford: Oxford University, 125-144.

[34] Swain, M. (1998). Focus on form through conscious reflection. In C. Doughty, and J. Williams (Eds.), Focus on Form in Classroom Second Language Acquisition. New York: Cambridge University Press, 64-81.

[35] Swain, M. (2000). The output hypothesis and beyond: mediating acquisition through collaborative dialogue. In: J. P. Lantolf, (Ed.), Sociocultural Theory and Second Language Learning. Oxford: Oxford University Press, 97-114.

[36] Swain, M. (2005). The output hypothesis: theory and research. In: E. Hinkel, (Ed.), Handbook on Research in Second Language Teaching and Learning. Mahwah: Lawrence Erlbaum, 471-484.

[37] Swain, M., Lapkin, S. (1995). Problems in output and the cognitive processes they generate: A step towards second language learning. Applied Linguistics 16, 371-391.

[38] Tomlin, R., and Villa, V. (1994). Attention in cognitive science and SLA. Studies in Second Language Acquisition 16, $185-204$.

[39] White, J. (1998). Getting the learners' attention: A typographical enhanced study. In C. Doughty and J. Williams (eds.), Focuson-form in classroom second language acquisition. New York: Cambridge University Press.

[40] Williams, J. (1999). Memory, attention, and inductive learning. Studies in Second Language Acquisition 21, 1-48.

[41] Zhang, X. (1993). English collocations and their effect on the writing of native and non-native college freshmen. Unpublished $\mathrm{PhD}$ Thesis, Indiana University of Pennsylvania: USA. 


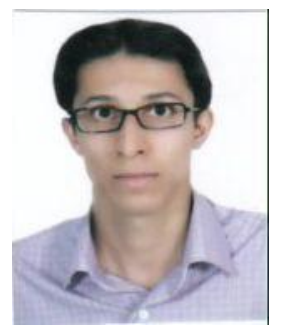

Ehsan Rezvani (b. 1982, Isfahan, Iran) is currently a Ph. D. candidate at the University of Isfahan, Isfahan, Iran. He received his M.A. in TEFL at the University of Isfahan (2007) following the completion of his B.A. in English Translation from Azad University of Khorasgan, Isfahan, Iran (2005). His main research areas of interest are: Second Language acquisition, Language Teaching Methodology, Discourse Analysis and Pragmatics. He has been working as an EFL instructor since 2000. 